\title{
7075-Al 合金の不連続変形
}

\author{
斉藤勝男* 細井吉一** 乙黒靖男*
}

J.Japan Inst.Metals, Vol.51,No.7(1987),pp.616-623

Discontinuous Deformation of 7075-Al Alloy

Katuo Saitou*, Yoshikazu Hosoi** and Yasuo Otoguro*

7075- Al alloy has been tensile tested in order to investigate the difference of discontinuous deformation models, and the rate process of discontinuous deformation by means of activation energy, and individual values of $m$ and $\beta$. Tensile tests have been performed in the temperature range mainly from 243 to $408 \mathrm{~K}$, in the strain rate range from $1.67 \times 10^{-5}$ to $6.67 \times 10^{-3} \mathrm{~s}^{-1}$. Changes in mechanical properties with or without discontinuous deformation are described. The main results obtained are as follows :

(1) Discontinuous deformation behavior can be divided into regions I and II, by the appearance of load-elongation curve and the strain rate dependence of critical strain, positive in region $I$ and negative in region II.

(2) Values of $m$ and $\beta$ are positive in region I, whereas in region II, the value of $\beta$ is positive but $m$ is negative.

(3) The activation energy is $49.3 \pm 2.5 \mathrm{~kJ} / \mathrm{mol}$ in region $\mathrm{I}$ and $108.0 \pm 1.0 \mathrm{~kJ} / \mathrm{mol}$ in region II. The rate process of the former is the vacancy-solute complex, and that of the latter appeared to be self diffusion of solute.

(4) A distinction of the models cannot be made by the calculation methods of activation energy.

(Received February 27, 1987)

Keywords: discontinuous deformation, 7075 aluminum alloy, dynamic strain ageing model, static stain ageing model, strain dependence of vacancy concentration, strain dependence of mobile dislocation density, tensile test, Portevin-LeChatelier effect

\section{I 。緒言}

溶質原子と転位との相互作用によって生じる合金の不連 続変形(いわゆる PL 効果)に関する研究は Cottrell の理 論 ${ }^{(1)}$ 以来, 多くの合金系で研究報告されており ${ }^{(2)}$, “理論的 取扱もなされている ${ }^{(3)-(6)}$. しかし，十分に解明されてい るわけではなく, 最近 Cottrell モデルとは異なったモデ $ル^{(7)(8)}$ が，また Cottrell モデルは不連続変形を説明する のに不適切であるという報告むなされている(9)-(11)(14).

不連続変形は荷重 - 伸び曲線上の荷重変動による鋸歯あ るいは変形帯伝播として認められ，その現れ方から数種の 型に分類し，不連続変形開始ひずみの温度およびひずみ速 度依存性の立場から論じられてきた。しかし，そてで用い られているパラメーター $m, \beta$ は常に $(m+\beta)$ の形で用い られており，個別の值として取り扱われていないのが現状 である. また不連続変形モデルとしての動的ひずみ時効モ
デルと静的ひずみ時効モデルの区別むなされていない，本 報告はこの点について 7075Al 合金を用いて調へ，不連続 変形発生機構について検討を加えることを目的としている. なお，不連続变形の有無による機械的性質の変化について 屯簡単に触れる。

不連続変形に関するモデルには現在大別して二つある. 第一は動的ひずみ時効モデル(1)であり，第二は静的ひずみ 時効モデル(3)(4)(12) と称されるあのである.

前者のモデルは運動転位が溶質原子の雾囲気を引きずる, あるいは溶質原子の雾囲気が運動転位を固着させるという 考え方である. この場合, その時の転位の臨界速度は次式 で与えられる。

$$
V_{\mathrm{c}} \approx 4 D / l
$$

乙こで $D:$ 溶質原子の拡散係数, $l\left(=U_{\mathrm{m}} b / k T\right)$ : 雾囲 気の有効半径, $b:$ バーガースベクトル, $U_{\mathrm{m}}$ : 転位と溶質 原子との結合エネルギーである. 置換型溶質原子の拡散は 変形初期では非常に小さいが変形によって導入された空孔

* 群馬大学工学部(Faculty of Technology, Gunma University, Kiryu)

** 群馬大学工業短期大学部, 現在 : 千葉工業大学金属工学科(College of Technology, Gunma University, Kiryu. Present address : Department of Metallurgical Engineering, Chiba Institute of Technology, Narashino) 
濃度の增加により促進され，転位の周りに雾囲気を形成し 転位速度を低下させる。乙れが不連続変形の生じる臨界条 件である，その時のひずみ速度は Orowan の式を用いる と次式で与えられる.

$$
\begin{gathered}
\dot{\varepsilon}=\frac{4 b \rho C_{\mathrm{v}}}{l} D_{0} \exp \left(-Q_{\mathrm{m}} / k T\right) \\
{\left[D=C_{\mathrm{v}} D_{0} \exp \left(-Q_{\mathrm{m}} / k T\right)\right]}
\end{gathered}
$$

乙てで $\rho$ : 可動転位密度, $C_{\mathrm{v}}$ : 空孔密度, $D_{0}$ : 拡散の振動 数因子, $Q_{\mathrm{m}}$ : 溶質原子の拡散の活性化エネルギーを示す. $Q_{\mathrm{m}}$ は, 空孔移動の活性化エネルギーを $E_{\mathrm{m}}$, 溶質原子之 空孔との結合エネルギーを $B$ とすると近似的に $Q_{\mathrm{m}}=E_{\mathrm{m}}$ 一 $B$ で与えられる。 また, $\rho$ と $C_{\mathrm{v}}$ は変形量に依存すると 仮定 ${ }^{(13)}$ されている.

$$
\begin{gathered}
\rho=K_{1} \varepsilon^{\beta}, C_{\mathrm{v}}=K_{2} \varepsilon^{m} \\
\left.\llbracket K_{1}, K_{2}: \text { 定数 }\right]
\end{gathered}
$$

式( 3 )を(2)に代入するてとにより不連続変形の生じる臨 界ひずみ $\varepsilon_{\mathrm{c}}$ は次式で与えられることになる。

$$
\begin{aligned}
\varepsilon_{\mathrm{c}}^{m+\beta} & =\frac{l \dot{\varepsilon}}{4 b K_{1} K_{2} D_{0}} \exp \left(Q_{\mathrm{m}} / k T\right) \\
& =\frac{\dot{\varepsilon} U_{\mathrm{m}}}{4 K_{1} K_{2} D_{0} k T} \exp \left(Q_{\mathrm{m}} / k T\right)
\end{aligned}
$$

後者のモデルは転位が障害物を乗り越える際の待ち時間 中に転位の周りに溶質原子の雾囲気が形成されるという考 え方である. 待ち時間 $t_{\mathrm{w}}$ は障害物間隔を $L$ とする之

$$
t_{\mathrm{w}}=\frac{L b \rho}{\dot{\varepsilon}}
$$

で与えられる．また，その場所で溶質濃度 $C_{1}$ の雾囲気を 形成するための時間 $t_{\mathrm{a}}$ は次で与えられる ${ }^{(15)}$.

$$
t_{\mathrm{a}}=\left(\frac{C_{1}}{\alpha C_{0}}\right)^{3 / 2} \cdot \frac{k T b^{2}}{3 D U_{\mathrm{m}}}=\left(\frac{C_{1}}{\alpha C_{0}}\right)^{3 / 2} \cdot \frac{b^{3}}{3 D l}
$$

ここで $C_{0}$ は溶質の平均濃度 $\left(C_{1} \gg C_{0}\right) . \alpha$ の值は $3^{(3)}$, $\pi^{(15)}, 3(\pi / 2)^{1 / 3(16)}$ が示されている. 不連続変形の生じる 条件は $t_{\mathrm{w}} \approx t_{\mathrm{a}}$ で与えられ，式(6)，(7)より次式が得ら 机る。

$$
\begin{aligned}
\dot{\varepsilon} & =\left(\frac{\alpha C_{0}}{C_{1}}\right)^{3 / 2} \cdot \frac{3 L \rho l C_{\mathrm{v}} D_{0}}{b^{2}} \exp \left(-Q_{\mathrm{m}} / k T\right) \\
& =\left(\frac{\alpha C_{0}}{C_{1}}\right)^{3 / 2} \cdot \frac{3 L \rho U_{\mathrm{m}}}{k T b} C_{\mathrm{v}} D_{0} \exp \left(-Q_{\mathrm{m}} / k T\right)
\end{aligned}
$$

また，式( 3 )を用いると臨界ひずみは

$$
\begin{aligned}
\varepsilon_{\mathrm{c}}^{m+\beta} & =\left(\frac{C_{1}}{\alpha C_{0}}\right)^{3 / 2} \cdot \frac{\dot{\varepsilon} b^{2}}{3 L K_{1} K_{2} l D_{0}} \exp \left(Q_{\mathrm{m}} / k T\right) \\
& =\left(\frac{C_{1}}{\alpha C_{0}}\right)^{3 / 2} \cdot \frac{b \dot{\varepsilon} k T}{3 L K_{1} K_{2} U_{\mathrm{m}} D_{0}} \exp \left(Q_{\mathrm{m}} / k T\right)
\end{aligned}
$$

で与えられる。

\section{II. 試料および実験方法}

本実験で用いた 7075Al 合金の分析值を Table 1 亿示 す.試験片は厚さ $1 \mathrm{~mm}$ の冷延板より平行部寸法, 幅
Table 1 Chemical analysis (mass\%) of 7075-Al alloy.

\begin{tabular}{c|c|c|c|c|c|c|c|c}
\hline \hline $\mathrm{Zn}$ & $\mathrm{Mg}$ & $\mathrm{Cu}$ & $\mathrm{Fe}$ & $\mathrm{Cr}$ & $\mathrm{Si}$ & $\mathrm{Ti}$ & $\mathrm{Mn}$ & $\mathrm{Al}$ \\
\hline 5.57 & 2.51 & 1.61 & 0.26 & 0.21 & 0.07 & 0.02 & 0.01 & Bal. \\
\hline
\end{tabular}

$5 \mathrm{~mm}$ ，長さ $20 \mathrm{~mm}$ の肩付き試験片を $\mathrm{NC}$ フライス加工 で作成した。乙の際, 試験片の長手方向と素材の圧延方向 とを同一にした。試験片の熱処理は $693 \mathrm{~K}, 3.6 \mathrm{ks}\left(420^{\circ} \mathrm{C}\right.$, $1 \mathrm{~h})$ の大気焼鈍後, 炉冷とし(結晶粒径約 $24 \mu \mathrm{m})$, 電解研 磨(液組成, 過塩素酸: アルコール =1:9, <293 K)を行っ た後，引張試験に供した．引張試験はインストロン型を用 い，初期ひずみ速度は $1.67 \times 10^{-5} \sim 6.67 \times 10^{-3} \mathrm{~s}^{-1}$ の範囲 で行った。試験温度は $201 \mathrm{~K}$, 扔よび $243 \sim 408 \mathrm{~K}$ の範囲 とし，201 K はドライアイス+アルコールを，243〜263 K は冷涷機で泠却したアルコールを， $273 \mathrm{~K}$ は氷水を， $313 \mathrm{~K}$ 以上ではシリコン油浴を用いた。温度制御は $\pm 0.5 \mathrm{~K}$ の 精度であった。

不連続変形開始ひずみはゼロサプレッションを行った荷 重 - 時間曲線より求めた. 不連続変形開始の判断としては 明瞭な荷重降下が生じる以前に荷重 - 時間曲線上にうねり が生じることからこれの発生位置を開始位置とした。

\section{III. 実 験 結 果}

\section{1. 不連続変形開始ひずみ}

温度,ひずみ速度を変えて測定した不連続変形開始ひず み $\left(\varepsilon_{\mathrm{c}}\right.$, 以後, 開始ひずみと称する $)$ のずみ速度 $(\dot{\varepsilon})$ 依存 性をFig.1亿示す．なお，ひずみ速度は初期ひずみ速度 を用いている.Fig.1(a)中で記号 No.は不連続変形が認 められなかったてとを示す．Fig.1(a)から開始ひずみは 温度一定ではひずみ速度の増加に伴い増加し, ひずみ速度 一定では温度の上昇に伴い開始ひずみは減少することがわ かる．しかし，温度の上昇に伴いての傾向之は全く逆の場 合，すなわち負の依存性の存在するてとが認められる (Fig.1(b)). 負の依存性が存在する場合には, 開始ひず みはひずみ速度の増加に伴って減少し, 最小值を経た後に 増加する正の依存性へ之続く．乙の最小值に相当するひず み速度は温度の上昇之共に増加する傾向にある. また, 直 線の勾配は正の依存性の場合においては温度上昇による変 化は少ないが，負の依存性では大きくなる(絶対值で)傾向 を有していることが認められる。こてで開始ひずみがひず み速度に正依存する場合を領域 I , 負に依存する場合を 領域 II と便宜的に定義しておく。

不連続変形出現の有無を絶対温度の逆数で整理した結果 をFig. 2 亿示す. 図中で $\times$ 印は不連続変形が生じなかっ た場合を示している.ての図から不連続変形の発生する場 合のひずみ速度と温度の組合せは図中の境界線 1 および 3 で区切られた領域内のあのでなければならないととが示さ れる。また，乙の領域内は前述の領域 I， II 考慮すると 

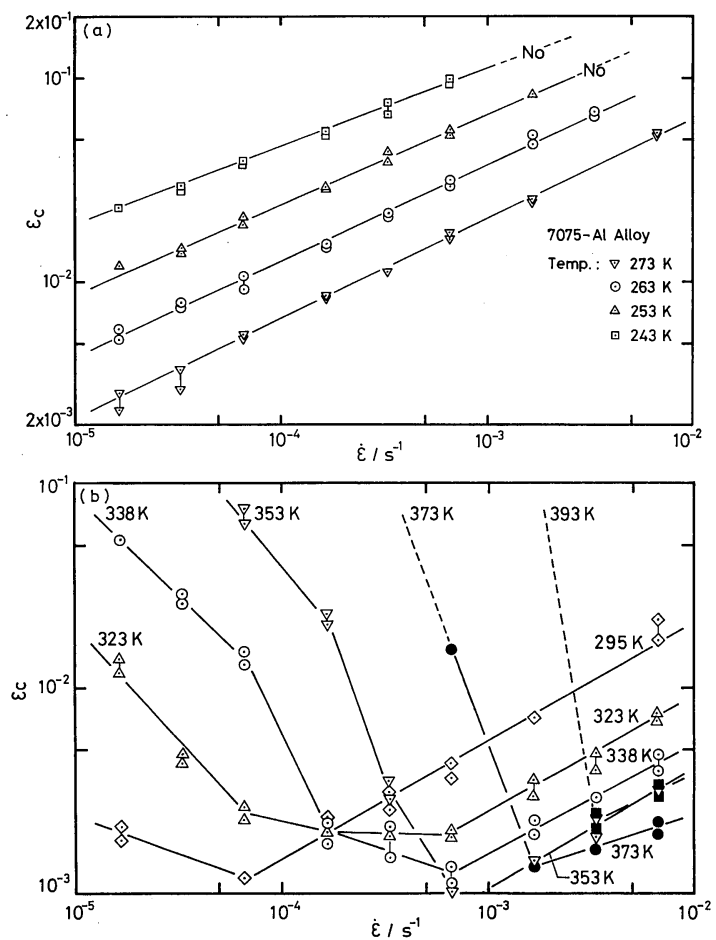

Fig.1 Relation between critical strain and strain rate.

(a) Under room temperature. No. denotes disappearance of serration.

(b) Above room temperature.

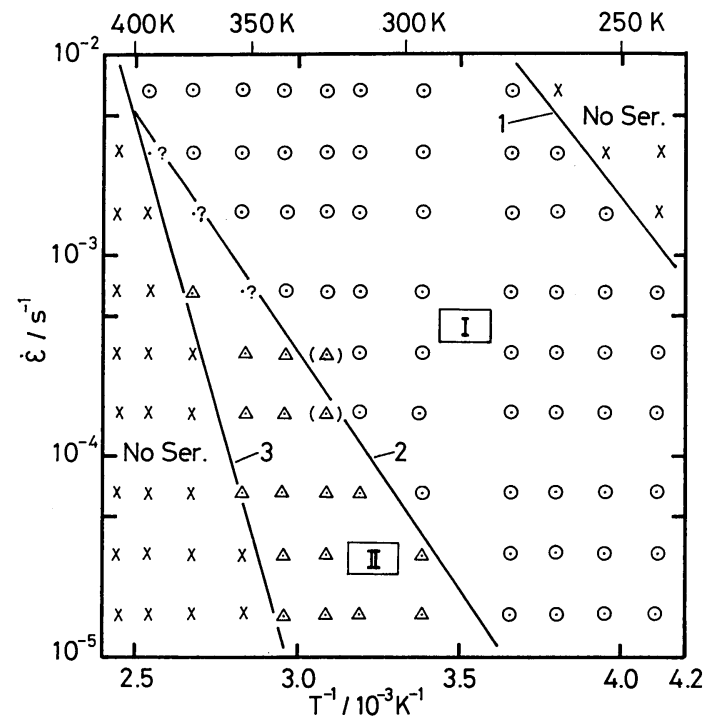

Fig.2 Relation between reciprocal absolute temperature and initial strain rate. Marks $\odot$ and $\triangle$ denote that serrations have appeared. Mark $\times$ denotes that serrations have not at all appeared. Regions I and II indicate that the strain rate dependence of critical strain is positive and negative, respectively.
直線 2 によって区分することが可能である．てれにより領 域 II の出現は，同一ひずみ速度では高温側で，同一温度で は低ひずみ速度側で生じるといえる，なお，? 印は領域 I ， Iのどちらに属するか判断出来なかったてとを示している． これは, Fig.1(b)中に打ける 353, 373, $393 \mathrm{~K}$ の場合に相 当する.

なお， $201 \mathrm{~K}$ の温度では不連続変形は認められなかった。

\section{2. 不連続変形曲線の形状}

不連続変形曲線の形状は領域 I ，II とではその現れかた に若干の相異があるので区別して示す.

また，形状の分類は研究者によって異なるのでててでは Brindley と Worthington の分類 ${ }^{(17)}$ とった。

（1）領 域 I

不連続変形曲線の代表的な例を Fig. 3 亿示す. Fig.3 (a)，打よび(b)は領域 I に押ける不連続変形開始直後, および変形中期の曲線を示している. 不連続変形開始点を 図中に矢印で示した. 不連続変形開始直後は不規則之思わ れる形状で変形が進行するが†，ある程度変形が進行 すると曲線の形状は明瞭な規則性を有するようになり (Type B)，乙の規則的な形状は破断まで継続する。不連 続变形開始直後の形状は Fig.3(a)に示した以外に，Fig.4

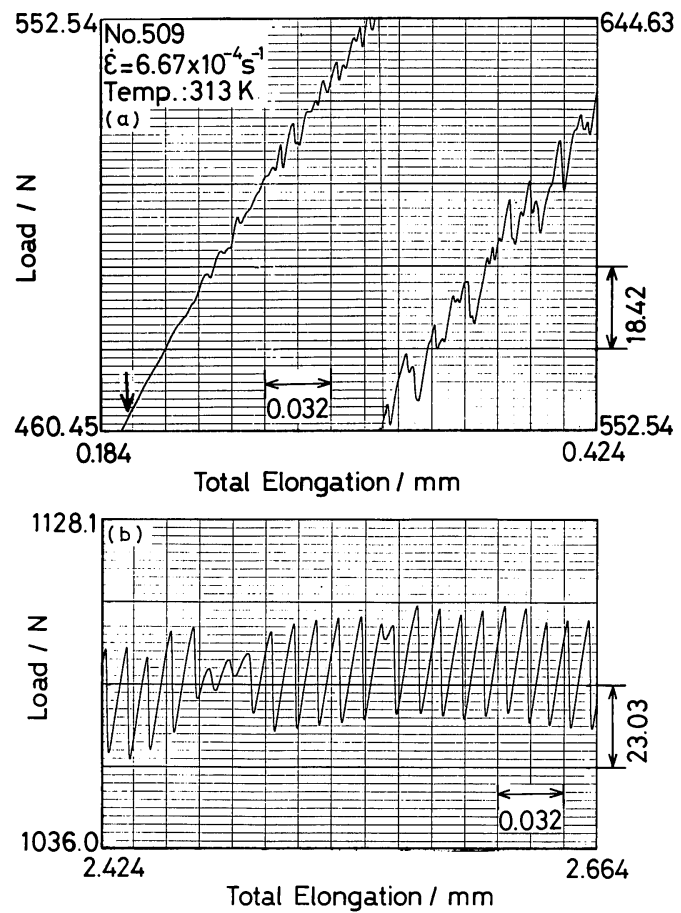

Fig.3 An enlarged portion of the load elongation curve in region I. The arrow in the figure indicates the starting point of serration.

(a) Initial portion of deformation, and (b) corresponding to nearly half of the total elongation.

$†$ Type A 中に数個のピークが生じた場合に相当する と考えられる. 


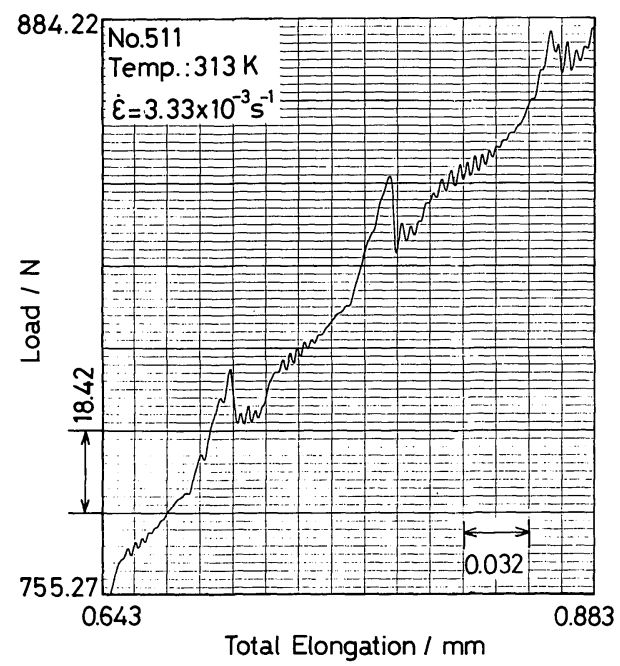

Fig.4 An enlarged portion of the load elongation curve superimposed type $B$ on type $A$ in region I .

に示すような規則性を有するいわゆる Type A が認めら れる場合があるが，変形が進行すると Type Bに変化す る. Fig.4は Type A 中に Type Bが出現した中間的な 場合に相当する. 同一試験片では Type A あしくは Fig.3 (a)に示した形で不連続変形が始まり, その後 Type Bに 遷移する. Type B の開始ひずみはひずみ速度の上昇に伴 い増加する傾向にあった。しかし，明瞭には判断し得ない 場合が多いため，本報告ではてのひずみについては触れな い.な拉, $273 \mathrm{~K}$ 以下の温度では Type A で主に変形が 進行した.

（2）領 域 II

領域 II に抢ける荷重 - 伸び曲線の代表例を Fig.5 亿示 す.乙の領域における不連続変形は荷重 - 伸び曲線上のゆ らぎに続いて急激な荷重降下の連続で示され，領域 Iにお ける不連続変形の現れかたとは全く異なっている，乙の現

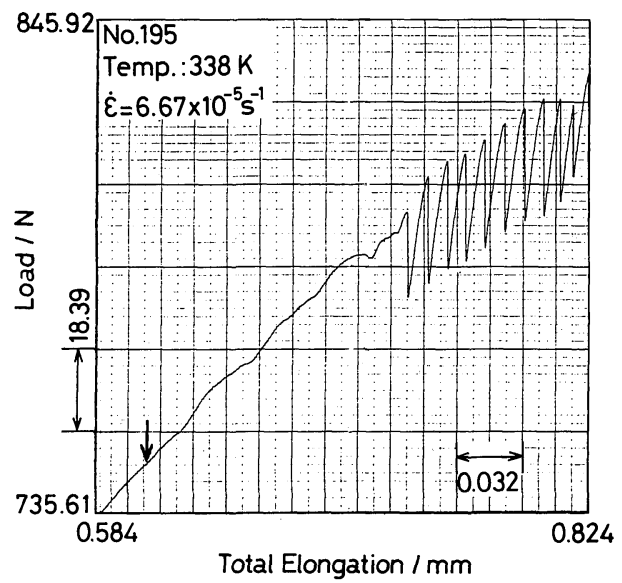

Fig.5 An enlarged portion of the load elongation curve in region $I I$. The arrow indicates the starting point of serration.
れ方は Brindley と Worthington ${ }^{(17)}$ によれば Type Cに 相当する。乙の Type C は前述の Type B と同様汇破断 時まで継続する。

Type B と C はその出現時には若干の相違が認められ るが，現れた後ではその相違を認めることは困難である (Fig.3(b) と Fig.5 とを比較). また, 荷重 - 伸び波形の 荷重増加部分の勾配は試験片の弾性変形にほぼ等しい勾配 を有している。なお，低ひずみ速度ではそれらの荷重降下 に対応して可聴音の発生を認めることが多かったてとを記 しておく

\section{3. 機械的性質}

$0.2 \%$ 耐力および引張強さ (UTS)のひずみ速度依存性の 例を各々 Figs.6, 7 亿示す† . Fig.6 から $0.2 \%$ 耐力は不 連続変形が生じる場合にはひずみ速度依存性は負になる傾 向を有している(Fig.2 参照)。しかし，生じない場合(408 K)であその依存性は非常に小さいため, 変形応力のひず み速度依存性への不連続変形の影響を確認するには $0.2 \%$ 耐力の場合よりも Fig.7 亿示すように引張強さの場合の 方が良好である．Fig.7では不連続变形が生じない場合に

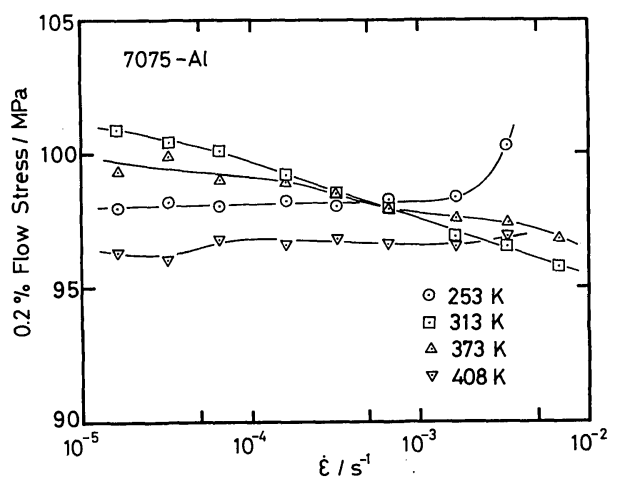

Fig.6 Relation between $0.2 \%$ flow stress and strain rate.

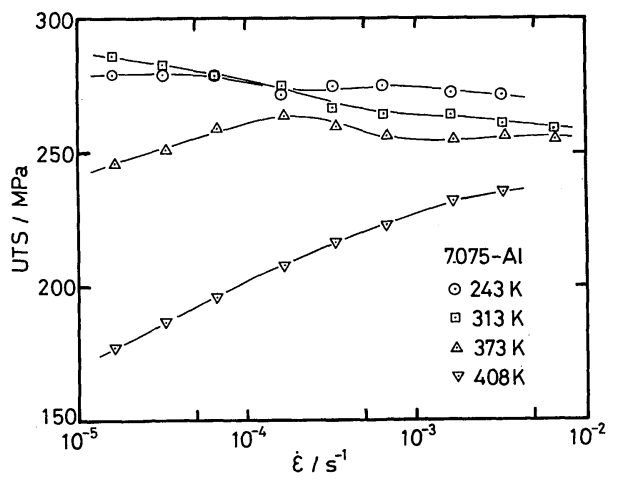

Fig.7 Relation between ultimate tensile strength and strain rate.

† 応力およびひずみはすべて真応力，および真ひずみ を用いた。 
は引張強さはひずみ速度に正に依存し $(408 \mathrm{~K})$, 生じる場 合には負に依存する $(313,243 \mathrm{~K})$. また, 中間のひずみ速 度から不連続変形が現れる場合にはそのひずみ速度を境に して依存性が変化することが示される $\left(373 \mathrm{~K}, 3.33 \times 10^{-4}\right.$ $\mathrm{s}^{-1}$ 以上のひずみ速度では不連続変形が生じる). Fig.8に 引張強さの温度依存性を示す. 図中で No.Ser.は不連続 変形が生じないことを示している. 従って, 不連続変形が 現れる温度までの引張強さの温度依存性は非常に小さいか あるいは正であるが, 不連続変形が現れなくなると引張強 さは急減する。

次に均一伸び(UTS までの伸び)および破断伸びの温度 依存性の例を Fig.9 に示す. 両者は室温前後で最小值を とり, 温度上昇と共に増加する. その後, 均一伸びは不連 続変形が発生しなくなる温度を境にして低下するが，破断 伸びは単調に増加する傾向にある.

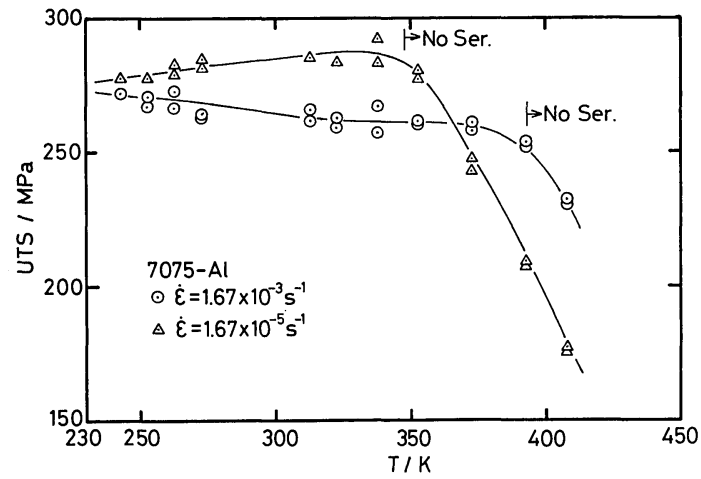

Fig.8 Relation between ultimate tensile strength and absolute temperature.

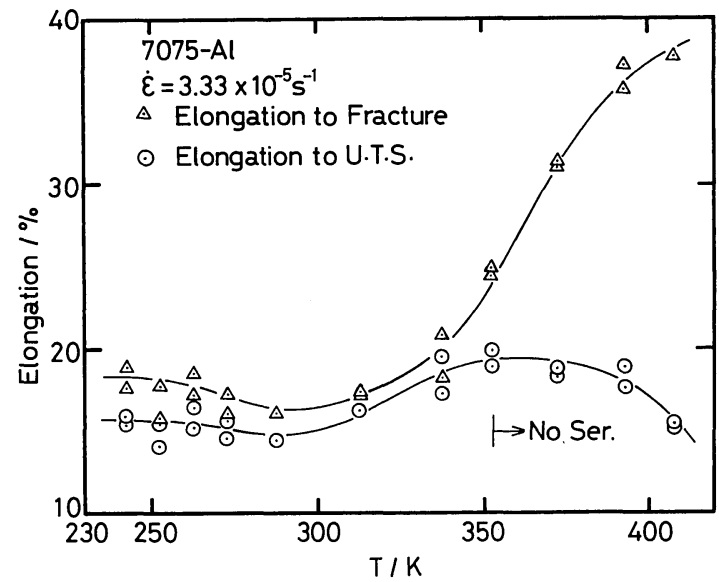

Fig.9 Relation between elongation and absolute temperature.

\section{4. $m$ および $\beta$}

不連続変形現象を記述する代表的なパラメータ $(m+\beta)$
は式(4)または (10)を用いて Fig.1(a)，(b)の直線の勾 配の逆数から求められる. 得られた結果を Table 2 に $(m$ $+\beta)_{\mathrm{E}}$ で示す.

\section{（1）領 域 I}

$(m+\beta)_{\mathrm{E}}$ はほぼ $1.7 \sim 2.6$ の範囲内にあり, $288 \mathrm{~K}$ 以下 では温度低下につれて増加するが，それ以上の温度では温 度に対する依存性は少ないように見受けられる。

$\varepsilon_{\mathrm{c}}$ の $\dot{\varepsilon}$ 依存性から求められるパラメータは常に $m$ 之 $\beta$ が加算された $(m+\beta)$ の形であるため, 不連続変形に対す る $m$ と $\beta$ の寄与が明確では無い. このため, $m$ と $\beta$ と を個別の值として求める必要があるが，乙てでは筆者らの 提案した方法に ${ }^{(18)}$ より $m$ と $\beta$ を分離して求め，その計算 值を $(m+\beta)_{\mathrm{c}}, m_{\mathrm{c}}$ および $\beta$ として Table 2 亿示した. ただし, 転位密度 $\rho$ と変形応力 $\sigma$ との関係を $\sigma \propto \rho^{1 / 2}$ 之 仮定して計算を行ってある. 計算值 $(m+\beta)$ c と実測値 $(m$ $+\beta)_{\mathrm{E}}$ は良い一致を示していることから解析方法は妥当で あると考えられる. $m_{\mathrm{c}}$ の值は $263 \mathrm{~K}$ 以上の温度では約 1.4 であり温度に依存しないが， $\beta$ の値は $313,323 \mathrm{~K}$ で他の 温度よりあ低い值を示している. $338 \mathrm{~K}$ 以上の温度では, 実験したひずみ速度範囲が限られているため，および領域 IIが現れることの影響により領域 I における $m$ と $\beta$ の分 離は出来なかった。

Table 2 Parameters obtained by experiment and calculation.

\begin{tabular}{c|l|c|c|c|c|c|c}
\hline \hline Temp.(K) & $(m+\beta)_{\mathrm{E}}$ & $N$ & $(m+\beta)_{\mathrm{c}}$ & $\beta$ & $m_{\mathrm{c}}$ & $N+1$ & $2 N+1$ \\
\hline Region I & & & & & & & \\
243 & 2.614 & 0.2714 & 2.604 & 0.5428 & 2.061 & 1.271 & 1.543 \\
253 & 2.237 & 0.3032 & 2.384 & 0.6065 & 1.777 & 1.303 & 1.606 \\
263 & 2.120 & 0.3052 & 2.054 & 0.6104 & 1.444 & 1.305 & 1.610 \\
273 & 2.045 & 0.3414 & 2.079 & 0.6828 & 1.396 & 1.341 & 1.683 \\
288 & 2.052 & 0.3078 & 2.057 & 0.6156 & 1.441 & 1.308 & 1.616 \\
295 & 1.714 & & & & & & \\
313 & 1.790 & 0.1784 & 1.815 & 0.3568 & 1.459 & 1.178 & 1.357 \\
323 & 1.762 & 0.2220 & 1.906 & 0.4440 & 1.462 & 1.222 & 1.444 \\
338 & 1.799 & & & & & & \\
& 1.869 & & & & & & \\
353 & 1.710 & & & & & & \\
373 & $(1.65)$ & & & & & & \\
393 & $(1.48)$ & & & & & & \\
Region II & & & & 0.6214 & -1.583 & 1.311 & 1.621 \\
338 & & 0.3107 & -0.9615 & 0.6214 & -1.277 & 1.279 & 1.557 \\
353 & & 0.2787 & -0.7198 & 0.5574 & -1.50 \\
\hline
\end{tabular}

\section{（2）領 域 II}

領域 Iにおける $(m+\beta)_{\mathrm{E}}$ は，Fig.1(b)に示したように データを直線で結ぶことが出来ないため求められなかった が, 計算値を Table 2 に示した. $(m+\beta)_{\mathrm{c}}$ の值は負であ り, 領域 I に比べて絶対值で約 $1 / 2$ の值を, $\beta$ は正の值で あるが， $m_{\mathrm{c}}$ は負の值を得た。 $(m+\beta)_{\mathrm{E}}$ が実験で求めら れなかったととと同じ理由により， $m_{\mathrm{c}}, \beta$ の值の誤差は 領域 I での值に比べて大きい，乙のため，領域 I とIIにお ける值の比較は行わなかった。 


\section{IV. 考察}

\section{1. $m$ および $\beta$}

\section{（1）領 域 I}

塑性変形によって導入される過剩空孔濃度のひずみ依存 指数 $m$ は Table 2 に示したように 1.4 2.0の範囲にあ る. 不連続変形の実験で求められている従来の $m$ 値は 1.0 〜1.5であるが, 試験温度を広範囲に变えて測定してはい ないため少なくとあ $263 \mathrm{~K}$ 以上の温度での $m$ 值は従来の 結果と一致していると考えられる.

従来の $m$ あるいは $\beta$ の説明は, $\beta=1$ とした場合の $m$ の理論値との比較 ${ }^{(19)}$ から, $\beta$ の值は考慮せず $m$ の值のみ

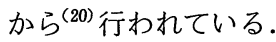

van Buren ${ }^{(21)}$ は理論的取扱いにより $m$ の值として 1.25 (単 一すべり), 2.0 (多重すべり)を得ている.また, Saada ${ }^{(22)}$ はジョグの非保存運動の考えから次式を導いた ${ }^{(23)}$.

$$
\mathrm{d} C_{\mathrm{v}} / \mathrm{d} \varepsilon \approx K \sigma(K: \text { 剛性率を含む定数 })
$$

これによれば応力のひずみ依存性を考えることにより $m$ 值が求まる. 次式を仮定すると,

$$
\sigma=f^{\prime} \varepsilon^{n}\left(f^{\prime}: \text { 定数 }\right)
$$

空孔濃度として,

$$
C_{\mathrm{v}}=K^{\prime} \varepsilon^{n+1}+C_{0}\left(K^{\prime}: \text { 定数, } C_{0} \text { : 積分定数 }\right)
$$

が得られる. 式( 3 ) と比較するととにより， $m$ は近似的 に次で与えられる。

$$
m=n+1
$$

通常, 単一の $n$ によって応力ーひずみ曲線は記述し得 ず，また， $n$ はひずみ速度によっても変わるため, 不連続 変形が開始するひずみでの $n$ を用いるべきである，乙の 值を $N$ とすると，

$$
m=N+1
$$

$\left(N=[\partial \ln \sigma / \partial \ln \varepsilon]_{\dot{\varepsilon}}, \sigma \leq \sigma_{\mathrm{s}}\right.$ : 開始応力, $\left.\varepsilon \leq \varepsilon_{\mathrm{c}}\right)$ こてで $N$ はひずみ速度には依存せず，温度に依存する。 この值を Table 2 に示した。 これによると $m$ 值は筆者ら による方法 ${ }^{(18)}$ での $m_{\mathrm{c}}$ 値と $263,273,288 \mathrm{~K}$ の温度でほぼ 一致した值であるが，それ以外の温度では $m_{\mathrm{c}}$ 值より低い 值を示す. こてで $\beta$ は次の関係， $\beta=2 N^{(18)}$ であるため, $\beta$ の最大值を 1.0 とすると $N=0.5$ となる. 従って Saada のモデルによる $m$ の最大值は 1.5 となる(最小值は 1 ).

Saada のモデルとは異なり Basinski と Saimoto ${ }^{(24)}$ は 次式を示した.

$$
C_{\mathrm{v}} \approx \int \sigma^{2} \mathrm{~d} \varepsilon
$$

式(13)を代入すると結果として，

$$
m=2 N+1
$$

となり, この値あ Table 2 に示した. 式(18)によって計 算した值は，313, $323 \mathrm{~K}$ では Saadaのモデルよりも $m_{\mathrm{c}}$ 值に近い，しかし， $243 \mathrm{~K}$ では $m_{\mathrm{c}}$ 值よりかなり低い值を 示す結果となった.

以上のことから，本実験で得られた $m$ 值は van Buren
の 1.25 2.0 の範囲内ではあるが，現時点では Saada の モデル, Basinski と Saimotoのモデルのいずれむ否定 し得ない。

（2）領 域 II

領域 I における $m$ 值は正であり, 変形の進行と共に過 剩空孔濃度が増加するてとを示しているが，領域Iでの $m$ の計算值は Table 2 亿示したように負の值として得ら れた．筆者等の提案した分離方法が領域 IIであ妥当である とするならば，すなわち，過剩空孔は変形と共に減少する ことを意味しており，過剩空孔が変形によって増加する前 述のモデルでは説明し得ない，筆者等はてれを説明するモ デルを有していないが，定性的には次のように考えられる． 変形による空孔の生成は領域 I の場合と同様であると仮定 すると, 結果としての過剩空孔濃度の減少は空孔消滅源の 増加に起因することになる．空孔消滅源としては粒界およ び刃状転位上のジョグが考えられる，後者に関しては領域 II の出現が領域 I に比べて低ひずみ速度かつ高温であるた め，空孔の有効な消滅源として作用し，刃状転位は空孔を 吸収して上昇運動すると考えられる．空孔生成量のひずみ 依存性よりあ空孔消滅量のひずみ依存性の方が大きいと仮 定すれば，結果的に空孔濃度はひずみの増加と共に減少す ることになり， $m$ 値は負になるであろう．てのように考 えると領域 II では溶媒あるいは溶質の自己拡散が不連続変 形の律速過程に関係していることを示すことになる。

\section{2. 活性化エネルギー}

霧囲気半径 $l$ が温度，ひずみに依存しないと仮定される 場合には $\varepsilon_{\mathrm{c}}$ と $\dot{\varepsilon}$ との関係は動的ひずみ時効モデルと静的 ひずみ時効モデルは同一であるため(式( 4 )，(10)参照), 活性化エネルギーは $\left[\log \varepsilon_{\mathrm{c}} \text { vs. } 1 / T\right]_{\dot{\varepsilon}}$ プロットの勾配, あるいは $[\log \dot{\varepsilon} \text { vs. } 1 / T]_{\varepsilon_{c}}$ プロットの勾配より求められ る. 従って活性化エネルギーからモデルの相違を検討する ことは出来ない.

$l$ が温度，ひずみに依存すると考えられる場合，および $(m+\beta)$ が温度によって異なる場合には動的ひずみ時効モ デルでは $\left[\log \varepsilon_{\mathrm{c}}^{(m+\beta)} \cdot T \text { vs. } 1 / T\right]_{\dot{\varepsilon}}$ プロットで, 静的ひず み時効モデルでは $\left[\log \varepsilon_{\mathrm{c}}^{(m+\beta)} / T \text { vs. } 1 / T\right]_{\dot{\varepsilon}}$ プロットで活 性化エネルギーを求める必要がある† .

活性化エネルギーを求める別な方法はひずみ速度を温度 の逆数で整理することにある．ただしての場合あ上述の理 由から $\varepsilon_{\mathrm{c}}$ 一定ではなく, $\varepsilon_{\mathrm{c}}^{(m+\beta)}$ 一定で行うべきであり， 動的ひずみ時効モデルでは $[\log \dot{\varepsilon} / T \text { vs. } 1 / T]_{\varepsilon_{c}^{m+\beta}}$ プロッ 卜を, 静的ひずみ時効モデルでは $[\log \dot{\varepsilon} T \text { vs. } 1 / T]_{\varepsilon_{c}}^{m+\beta}$ プロットを用いる† 。

従来の報告では活性化エネルギーは $\log \varepsilon_{\mathrm{c}}$ vs. $1 / T$ あ るいは $\log \dot{\varepsilon}$ vs. $1 / T$ プロットのみで求めて打り, 求め方 を変えて比較した例は少ない，Qian とRead-Hill ${ }^{(25)}$ は

$\dagger$ 不連.続変形の温度範囲が狭い場合には $\log \varepsilon_{\mathrm{c}}^{m+\beta}$ vs. $1 / T\rfloor_{\dot{\varepsilon}},\{\log \dot{\varepsilon} \text { vs. } 1 / T]_{\varepsilon_{C}^{m+\beta}}$ として良い. 
$\mathrm{Cu}-3.1 \mathrm{~mol} \% \mathrm{Sn}$ 合金で, Mukherjee ${ }^{(26)}$ は $5005 \mathrm{Al}$ 合 金で $\log \dot{\varepsilon}$ vs. $1 / T$ で求めた活性化エネルギーの值は $\log \varepsilon_{\mathrm{c}}$ vs. $1 / T$ プロットで求めた值と良い一致を示した と述べている．また，Chaturvedi と Lloyd ${ }^{(27)}$ は Mg-10 $\operatorname{mass} \% \mathrm{Ag}$ 合金において $\log \dot{\varepsilon} T$ vs. $1 / T$ プロットで活 性化エネルギーの值 $50.2 \mathrm{ks} / \mathrm{mol}, \log \varepsilon_{\mathrm{c}} \mathrm{vs} .1 / T$ で 44.4 $\pm 9.7 \mathrm{~kJ} / \mathrm{mol}$ を得ている.

本実験では $(m+\beta)_{\mathrm{E}}$ の值は温度によって变化している ためこれを考慮して活性化エネルギーを求めた. Fig.10 に〔log $\varepsilon_{\mathrm{c}}^{m+\beta} \cdot T$ vs. $\left.1 / T\right\}_{\dot{\varepsilon}} フ^{\circ}$ ロットを, Fig. 11 亿 $\log \dot{\varepsilon}$ $T$ vs. $1 / T]_{\varepsilon_{\mathrm{c}}+\beta}$ プロットを示す．前者での活性化エネル ギーは $48.9 \pm 2.1 \mathrm{~kJ} / \mathrm{mol}$ ，後者では $50.6 \pm 1.1 \mathrm{~kJ} / \mathrm{mol}$ を得た。また，ててには示さないが, 〔 $\log \varepsilon_{\mathrm{c}}^{m+\beta}$ vs. $\left.1 / T\right]_{\dot{\varepsilon}}$ プロットでの活性化エネルギーは $\left[\log \varepsilon_{\mathrm{c}}^{m+\beta} \cdot T \text { vs. } 1 / T\right]_{\dot{\varepsilon}}$ プロットとほぼ同様な值を, $[\log \dot{\varepsilon} \text { vs. } 1 / T]_{\varepsilon_{c}^{m+\beta}}$ での值

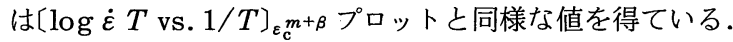
てのため, $l$ の温度依存性は無視してあ良く, 静的ひずみ 時効モデルと動的ひずみ時効モデルの差は認められないと 考えられる

活性化エネルギーはFigs.10,11で求められるが，不連 続変形の領域図(Fig.2)加ら求められる. $\dot{\varepsilon}=\dot{\varepsilon}_{0} \exp$ $(-Q / k T)$ を仮定すると, 直線 1 では $43.4 \pm 3.0 \mathrm{~kJ} / \mathrm{mol}$, 直線 2 では $45.8 \pm 0.6 \mathrm{~kJ} / \mathrm{mol}$ ，直線 3 では $108.4 \pm 1.0$ $\mathrm{kJ} / \mathrm{mol}$ を得た．領域 II の活性化エネルギーは前述の方 法では得られなかったが，領域 I を示す直線 1,2 の值が前

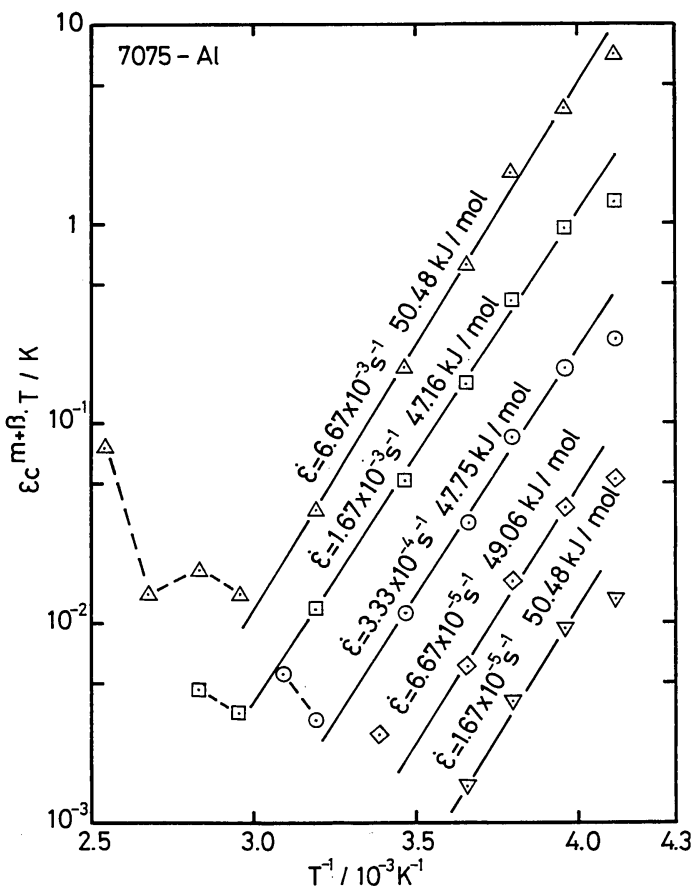

Fig.10 Relation between $\varepsilon_{c}^{m+\beta} T$ and raciprocal absolute temperature. Strain rate varies from $1.67 \times 10^{-5}$ to $6.67 \times 10^{-3} \mathrm{~s}^{-1}$. Broken lines correspond to region II .

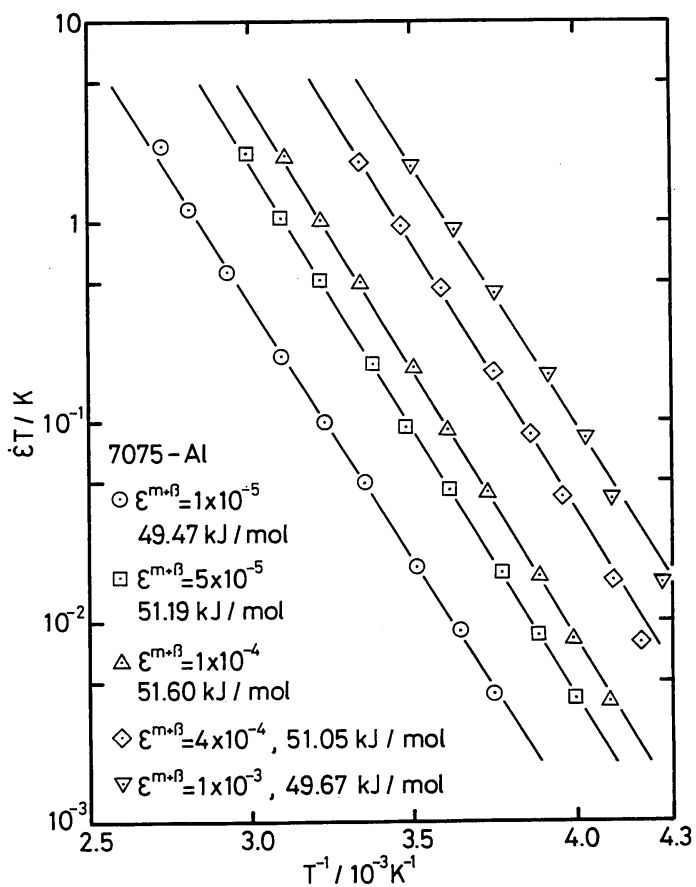

Fig.11 Relation between $\dot{\varepsilon} T$ and reciprocal absolute temperature in region $\mathrm{I}$.

述の方法の値と近い值を示しているてとから，アレニウス 型の式を用いて得た直線 3 の値は領域 II の活性化エネルギー の値であると考えられる．乙れらの值抢よび前述の值をす べて考慮すると，領域 I では $49.3 \pm 2.5 \mathrm{~kJ} / \mathrm{mol}$ を，領 域Iでは $108.4 \pm 1.0 \mathrm{~kJ} / \mathrm{mol}$ として良い。

純 $\mathrm{Al}$ 中の単一空孔の移動の活性化エネルギー 59.8 $\mathrm{kJ} / \mathrm{mol}^{(28)}$ と比較して領域 I の活性化エネルギー49.3 $\pm 2.5 \mathrm{~kJ} / \mathrm{mol}$ はかなり低い. ての差は溶質元素と空孔と の結合エネルギーを考えることによって説明されてい $3^{(26)(29)-(31)} .7075 \mathrm{Al}$ 合金の主要添加元素 $\mathrm{Zn}, \mathrm{Mg}, \mathrm{Cu}$ の 空孔との結合エネルギーは ${ }^{(32)}, \mathrm{Zn}: 20.3 \mathrm{~kJ} / \mathrm{mol}, \mathrm{Mg}$ : $18.3 \mathrm{~kJ} / \mathrm{mol}, \mathrm{Cu}: 4.8 \mathrm{~kJ} / \mathrm{mol}$ であり，乙れを考慮する と空孔移動の活性化エネルギーは 69.6〜 54.1 $2.5 \mathrm{~kJ} /$ $\mathrm{mol}$ となり，少なくとあ現時点では $59.8 \mathrm{~kJ} / \mathrm{mol}$ と良い 一致をしているとみなせる．従って, $7075 \mathrm{Al}$ 合金の領域 I での不連続変形は，その種類は分からないが溶質と空孔 之の複合体の拡散が律速していると考えられる.

領域 II の活性化エネルギー $108.4 \pm 1.0 \mathrm{~kJ} / \mathrm{mol}$ は領域 I でのそれの約 2 倍であり, 純 $\mathrm{Al}$ 中の空孔移動の活性化 エネルギーより非常に高く, むしろ $\mathrm{Al}$ 中の溶質拡散の活 性化エネルギー ${ }^{(33)}$ に近い，領域 I に比べ領域 IIでのての ような高い值は $7075 \mathrm{Al}^{(29)}, \mathrm{Al}-\mathrm{Mg}^{(31)(35)}, \mathrm{V}-\mathrm{C}^{(34)}$ で報告 されているが，真の解決はされていないようである.

領域 II での高い活性化エネルギーの説明として, Mukherjee ら ${ }^{(29)}$ は見かけ上の可動転位密度の減少による とし，松浦ら ${ }^{(36)}$ は平衡雾囲気からの離脱条件によるとし 
ている。しかし, 可動転位密度が変形の進行と共に減少す ることは変形が進行し加工硬化が生じている場合には考え にくい．前述したように領域 II での $m$ 值は領域 I とは逆 に負の值であり， $\beta$ は正である. このことは転位密度は増加 するが，過剰空孔濃度は変形の進行と共に減少することを 意味している．また，領域 II の現れる条件は高温かつ低ひ ずみ速度側であるため, 過剩空孔濃度の減少は十分に考え られることである．溶質原子の拡散は過剩空孔によって促 進されると仮定しているため, 過剰空孔濃度の減少は溶質 拡散の機構が空孔媒介ではなく, 自己拡散へ変化する可能 性を示している. 従って, 領域 II での不連続変形発生の機 構は領域 I とは異なり，溶質の自己拡散が支配していると 考えられる。

\section{V. 結 言}

$7075 \mathrm{Al}$ 合金の引張試験による不連続変形挙動を主に 243 〜 $408 \mathrm{~K}$ の温度範囲で調べた結果をまとめると以下のよう である。

(1) 動的ひずみ時効モデルと静的ひずみ時効モデルとの 相違は実験結果からでは認められない。

(2) 領域 I における $m$ 值は正であるが, 領域II では負 であった． $\beta$ の值は領域 I， II 共に正であった.

(3) 領域 I および II における活性化エネルギーとして $49.3 \pm 2.5 \mathrm{~kJ} / \mathrm{mol}$, および $108.0 \pm 1.0 \mathrm{~kJ} / \mathrm{mol}$ を得た.

(4) 不連続変形開始を支配している拡散機構は領域 I で は溶質と空孔との複合体の拡散，領域 II では溶質の自己拡 散であると考えられる。

終わりに，本報告をまとめるに際し有意義な助言を戴い た東京大学工学部 木原諒二教授に感謝致します。また, 試料を提供して下さった古河アルミニウム工業(株)日光研 究所の各位に御礼申し上げます。

\section{文献}

(1) A.H.Cottrell : Philos. Mag., 44(1953), 829.

( 2 ) E.O.Hall : Yield Point Phenomena in Metals and Alloys, McMillan, (1970).

(3) P.G.McCormick: Acta Metall., 20(1972), 351.

(4) R.A.Mulford and U.F.Kocks: Acta Metall., 27(1979), 1125.

( 5 ) P.Penning : Acta Metall., 20(1972), 1169.
(6) A.van den Beukel : Phys. Status Solidi (a), 30 (1975), 1125.

( 7 ) G.Schoeck: Acta Metall., 32(1984), 1229.

(8) R.B.Schwartz and L.L.Funk: Acta Metall., 33(1985), 295.

(9) E. Pink and A. Grinberg : Acta Metall., 30 (1982), 2153 ; Verformung und Bruch, Ed. H.P. Stuwe, Osterreichischen Akademie der Wissenschaften, (1981), p.117.

(10) E.Pink : Scr. Metall., 17(1983), 847.

(11) R. Onodera, T. Ishibashi, M. Koga and M. Shimizu : Acta Metall., 31(1983), 535.

(12) A.W.Sleeswyk : Acta Metall., 6(1958), 598.

(13) R.K.Ham and D.Jaffrey : Philos. Mag., 15 (1967), 247.

(14) R. Onodera, T. Ishibashi, H. Era and M. Simizu : Acta Metall., 32(1984), 817.

(15) J. Friedel : Dislocations, Pergamon Press, (1964), p.405.

(16) A.H.Cottrell and B.A.Bilby: Proc. Phys. Soc. London, A62(1949), 49

(17) B.J.Brindley and P.J.Worthington : Metall. Rev., 15(1970), 101.

（18）斉藤勝男，細井吉一，日景武夫 : 日本金属学会誌, 49(1985), 507.

(19) T. G. Langdon and F. A. Mohamed : Scr. Metall., 7(1973), 1199.

(20) D.J.Lloyd : Scr. Metall., 8(1974), 1025

(21) H.G.van Buren : Acta Metall., 6(1955), 519.

(22) G.Saada: Electron Microscopy and Strength of Crystals, Ed. G.Thomas and J.Washburn, Interscience, (1963), p.651.

(23) J.Friedel : 文献 (15), p.274.

(24) Z.S.Basinski and S.Saimoto: Can. J. Phys., 45(1967), 1161.

(25) K.W.Qian and R.E.Read-Hilll : Acta Metall. 31 (1983), 87.

(26) K.M.Mukherjee, T.May, C.D'Antonio and R. J.Maciag : Metall. Trans., 1(1970), 3233.

(27) M. C. Chaturvedi and D. J. Lloyd : Philos. Mag., 30(1974), 1199.

(28) A.Seeger and H. Mehrer: Vacancies and Interstitials in Metals, Eds. A. Seeger, D. Schamacher and J.Diehl, North-Holland, (1970), p.1.

(29) K.Mukherjee, C.D'Antonio, R.Maciag and G.Fisher: J. Appl. Phys., 39(1968), 5434

(30) K.Mukherjee, T. May, R.Maciag and C.D' Antonio : Mat. Sci. Eng., 6(1970), 334.

(31) C.N.Rao, T, Ramachandran and G.S.Murty : J. Mat. Sci. Let., 5(1986), 93.

(32) A.J.Perry and K.M.Entwistle: J.Inst. Met. 96(1968), 344.

(33) 平野賢一: 軽金属, 29(1979), 249.

(34) H.Yoshinaga, K.Toma, K.Abe and S.Morozumi : Philos. Mag., 23(1971), 1387.

（35）池野進，渡辺撒也，多々静夫：日本金属学会誌， 47(1983), 231.

（36）松浦圭助，西山丈司，幸田成康：日本金属学会誌, 31(1967)，1042. 